\title{
Stock Prices and Fundamentals in a Production Economy
}

\author{
Michael T. Kiley* \\ Federal Reserve Board \\ Washington, DC 20551 \\ mkiley@frb.gov \\ 202.452 .2448
}

August, 1999

Revised: January, 2000

\begin{abstract}
This paper compares the predictions for the market value of firms from the Gordon growth model with those from a dynamic general equilibrium model of production. The predictions for movements in the market value of firms in response to a decline in the required return or an increase in the growth rate of the economy are quantitatively and qualitatively different across the models. While previous research has illustrated how a drop in the required return or an increase in the growth rate of the economy can explain the runup in equity values in the 1990s in the Gordon growth model, the consideration of production overturns these results and illustrates that auxiliary implications of such shifts in fundamentals, such as a sharp increase in the investment intensity of the economy, are not supported by the data in the late 1990s. This tension between theory and data suggests that the skyrocketing market value of firms in the second half of the 1990s may reflect a degree of irrational exuberance.
\end{abstract}

Keywords: asset pricing, investment JEL Codes: G00, E20

"This paper is a substantially revised version of an earlier paper entitled "Prices and Quantities: Does A Drop in the Required Return to Equity Explain the Recent Rise in Stock Prices". This research was facilitated by the excellent research assistance of Ojas Desai, Betsy Vrankovich, and Joanna Wares. This research has benefitted from comments by Eileen Mauskopf, John Roberts, Karl Whelan, and seminar participants at the Federal Reserve Board and the University of Maryland. Responsibility for any errors lies solely with the author. The views expressed herein are the author's and do not reflect those of the Federal Reserve Board or its staff. 
In the late 1990s, the US stock market has taken off, leaving conventional valuation benchmarks such as dividend yields or P/E ratios very far from historical averages. Several recent analyses have suggested that the old benchmarks no longer apply because the US economy has entered a period of faster growth and lower required returns--two changes that imply a large runup in equity markets in the familiar Gordon (1962) growth model. This paper considers such shifts in "fundamentals" in a standard dynamic general equilibrium model with production, and concludes that consideration of production decisions alters--quantitatively and qualitatively--the ability of faster growth prospects or lower required returns to explain the runup in the market value of firms. This conclusion arises because faster growth prospects do not increase the ratio of market value to output in a production economy (in contrast to the Gordon model result) while a decline in the required return provides much less boost to equity prices in the production economy than in the Gordon model. In addition, a drop in required returns has auxiliary implications that are not supported by the data. In particular, a drop in the required return leads to increased investment in a general equilibrium model with production. The investment performance of the economy, while good in recent years, continues to lie at or below historical averages, suggesting that a shift towards greater investment driven by lower required returns or faster growth prospects has not occurred.

Most previous discussions of the relationship between the market value of firms and fundamentals have taken place in the Gordon growth model relating a stock price to the present discounted value of dividends. Such discussions assume that a range of important variables that determine the market value of firms are exogenous. For example, previous research has typically assumed that the growth rate of earnings and the required return to equity may have deviated from historical averages in recent years in a number of ways, and then examine the likely consequences of such shifts. These discussions may be misleading because the growth rate of an economy and the required return to equity are not exogenous; these variables are jointly determined by the interaction of savings and investment opportunities and the pace of technological progress.

For example, typical general equilibrium growth models, such as the model used below, imply that interest rates increase when the growth rate of the economy increases. This increase 
occurs because the required return (or interest rate) reflects consumers' willingness to substitute future consumption for current consumption, and an increase in growth implies that consumers require a higher interest rate today in order to save for tomorrow (when consumption will be higher because of the growth of the economy). When interest rates are linked to growth in this manner, an increase in growth raises both the amount that current investors can expect to be paid in the future (as emphasized by researchers using the Gordon growth model) and the discount rate--implying a lower present value of future payments relative to the case where interest rates are exogenously fixed. Given these offsetting effects, the market value of firms need not increase if future payments increase because of better growth prospects.

In addition, the payouts from firms--or simply dividends in the model below--are not independent of growth prospects or the required return in a general equilibrium production economy; shifts in these variables alter investment and production decisions, and hence alter retained earnings and dividends. For example, a drop in the required return to equity leads firms to increase investment (as more investment projects are now capable of earning the required return) and decrease dividends. The drop in dividends implies that the market value of firms rises less in response to a drop in the required return to equity in a production economy than in the Gordon growth model, where dividends do not fall. This effect is quantitatively quite important (in a calibrated model), and substantially mutes the degree of runup in the market value of firms in response to a drop in the required return relative to the numerical exercises that have used partial equilibrium models.

The speculation regarding whether the surge in equity values in recent years stems from fundamentals is just that--speculation. The high degree of uncertainty stems both from the inherent difficulty in tying high-frequency movements in equity markets to observable fundamentals, and from the inherent unobservability of shifts in fundamentals such as the required return to equity or an increase in the growth rate of the economy, as such shifts will only be apparent in the future after the improved growth experience or lower returns show up in the data. As noted by many researchers--such as Carlson (1999), Heaton and Lucas (1999) and IMF (1999a,1999b)--a variety of different combinations of future growth rates or required returns can justify the runup in equity values in the US and elsewhere in recent years. Unfortunately, if 
one solely looks at equity prices to determine values of the required return or growth rate consistent with the current market value of firms, then one cannot test whether such shifts have occurred because the values are chosen to match the data. The exercises below will illustrate the implications of shifts in fundamentals for the economy beyond equity markets by considering a general equilibrium model of production; one can examine the plausibility of different hypotheses regarding shifts in required returns or increases in growth by looking beyond equity markets and take some steps to overcome the observability problem inherent in the previous literature. The model predicts changes in the economy outside of equity markets, with especially strong increases in investment predicted to follow from a drop in required returns. Such an increase in investment is not obvious in the US data, providing another piece of evidence suggesting that the behavior of asset markets in recent years may not stem from the types of shifts in fundamentals suggested by optimists such as Glassman and Hassett (1999a, 1999b) or Siegel (1999).

Section 1 discusses the recent research that has examined the market value of firms in the Gordon growth model. Section 2 present the model with production and discusses the initial calibration. Section 3 presents results for a drop in the required return and section 4 presents results for an increase in productivity growth. The results suggest that the runup in the market value of firms is inconsistent with the production performance of the economy in recent years

\section{Recent Research on the Market Value of Firms}

A brief review of recent experience is useful to set the stage. Under the assumption that the securities issued by firms are claims to their stock of physical capital--and assuming that physical capital is near its long-run level (because adjustment costs are modest, for example) and the economy is competitive--the value of the stock of physical capital should equal the value of the securities issued by firms. ${ }^{1}$ Figure 1 graphs the market value of firms in the nonfarm business sector and the current cost physical capital stock held by the nonfarm business sector over the

${ }^{1}$ Actually, complications in the tax code make the relationship a bit more complex, but that have not been significant changes in the tax code in the last five years that can explain the surge in equity markets, and I follow previous authors (e.g., Hall (1999)) in ignoring taxes. 
postwar period. ${ }^{2}$ Between 1991 and 1998, the current cost stock of physical capital (plant and equipment) held by the nonfarm business sector grew 2.7 percent per year (on average) while the market value of firms in the nonfarm business sector rose 13 percent per year. By 1998, the ratio of the market value of firms to the value of physical capital--Tobin's Q--equaled 1.4--far above the average in the postwar period. The historically unprecedented divergence between these two series--which is also apparent in the ratio of equity prices to dividends or earnings--is the stylized fact to be explained in the models considered below.

Most recent discussions of the surge in the market value of firms in the 1990s have used the standard present value relation equating the market value of firms $(\mathrm{V})$ to the present discounted value of dividends (D)--the Gordon (1962) model--

$$
\mathrm{V}(\mathrm{t})=\sum_{\mathrm{j}=t+1}^{\infty} \mathrm{D}(\mathrm{t}) /(1+\mathrm{r})^{(\mathrm{j}-\mathrm{t})}
$$

where $r$ is the discount rate (which is assumed to be constant). Equating the market value of firms to the present discounted value of dividends ignores debt; most commentators have taken the more narrow view and focused solely on the equity value of firms. Below, I will examine the market value of firms including debt when I consider the implications of parameter changes in a standard general equilibrium model, and I will henceforth abuse language and interchangeably refer to the market value of firms and equity values.

A particularly simple case assumes that $\mathrm{D}$ grows at a constant rate $\mathrm{g}$, in which case $\mathrm{V}=\mathrm{D} /(\mathrm{r}-\mathrm{g})$

and the dividend price ratio is given by

$$
\mathrm{D} / \mathrm{V}=(\mathrm{r}-\mathrm{g}) \text {. }
$$

2 The data on output, investment, and capital stocks used in this study cover the nonfarm business sector of the US economy--the sector of primary interest in the Bureau of Labor Statistics' multifactor productivity releases. The most recent BLS data cover the period 1948 to 1997; the data are extended through 1998 in the manner discussed in Kiley (1999). When discussing real values, all nominal series are deflated with the price deflator for nonfarm business output.

The value of the financial securities issued by the nonfarm business sector are taken from the Flow of Funds accounts of the Federal Reserve Board. The market value of firms equals the market value of outstanding equities plus the value of financial liabilities less financial assets. 
According to this formula, the dividend-price ratio is a decreasing function of the growth rate of dividends and an increasing function of the required return to equity. Assuming typical values for the growth rate of dividends (about 3 percent since WWII according to Carlson (1999)) and the required return to equity (about 7-1/2 percent since WWII according to Siegel (1999)) yields a dividend price ratio of about 4.5 percent. By way of comparison, the average dividend-price ratio for the S\&P500 between 1974 and 1993 equaled 4.2 percent. Taking a longer perspective, Campbell and Shiller (1872) report that the average dividend price ratio since 1872 has been 4.7 percent--pretty close to the back-of-the-envelope guess implied by the Gordon model.

Recent dividend-price ratios have been far below this average; in 1998 the dividend-price ratio for the S\&P500 averaged 1.5 percent--the lowest value since the beginning of the data (1872) compiled by Campbell and Shiller. The historically high level of equity prices relative to dividends--combined with the high value of Tobin's Q shown in figure 1--has led numerous commentators and academics to ask whether equity markets are overvalued or if the old yardsticks no longer apply. Perhaps the most often-cited public comment to this effect was the musing on investors possible "irrational exuberance" by Federal Reserve Chairman Alan Greenspan in the fall of 1996.

In more academic circles, Campbell and Shiller (1998) have interpreted the low dividendprice ratio as a signal that equities are overvalued and that the medium-term outlook for equity returns is poor. Their conclusion follows from a careful historical analysis that shows how previous historical episodes with below average dividend-price ratios have been followed by mean reversion in this ratio. Further, they demonstrate that this mean reversion arises from an adjustment in prices, not dividends, implying that a low value for D/V leads to below average increases in equity values. The Economist uses similar reasoning in arguing that the US is a "bubble economy".3 Heaton and Lucas (1999) consider whether changes in fundamentals such as stock market participation, risk aversion, or time preference may have lowered the required

${ }^{3}$ The Economist has repeatedly issued warnings regarding "America's Bubble Economy" (for example, see the issue dated April 18, 1998). For an explicit discussion of the Gordon growth model in the Economist, see the article on "Valuing Shares" in the December 4, 1999 issue. 
return to equity and resulted in a lower equilibrium level of the dividend-price ratio; overall, they conclude that even large changes in these parameters can explain at most half of the decreased ratio of dividends to equity prices--again suggesting some bubble component to equity values in 1998. The analysis of Heaton and Lucas is similar to that below in that these authors employ a general equilibrium model; however, the model they consider is of an endowment economy (i.e., an economy with an exogenous output and dividend stream), so Heaton and Lucas do not examine the implications of changing fundamentals on production and investment, which will be the primary focus below. The analysis in a production economy will illustrate how dividends react to a change in the required return to equity--a consideration absent from the analysis in earlier work (except for the partial equilibrium analysis of Roberts (1999)). ${ }^{4}$

Other research has suggested that the current low value of the dividend-price ratio does not signal overvaluation of equities. Siegel (1999) suggests that the required return to equity may have fallen from its historic average of 7-1/2 percent because new technologies in financial services have lowered transaction costs. He suggests that the return to investors historically has been close to 5 percent--with the difference from the 7-1/2 percent return on a broad equity index representing transaction costs--and that the elimination of these transaction costs implies that in the future the return to equity will be 5 percent. In addition, Siegel argues that broad market equity indexes now are more heavily-skewed towards fast-growth industries, and hence the recent strength in earnings growth is likely to continue, necessitating to a higher value of $g$ in the present value calculation above. For example, simply lowering $\mathrm{r}$ to 5 percent and maintaining $\mathrm{g}$ at 3 percent would lower the equilibrium dividend-price ratio to 2 percent--considerably closer to the value in 1998 than the 4-1/2 percent derived from conventional assumptions. A small increase in $g$ would deliver an even lower implied dividend yield and hence suggest even less

${ }^{4}$ Roberts (1999) examines the response of investment, dividends, and stock prices to shifts in required returns and productivity in a model with exogenously fixed interest rates and labor supply--abstracting from the saving and output effects of such shifts. This focus limits his attention to the response of financial markets to shocks. The focus below on responses outside of financial markets illustrates the auxiliary testable implications of such shifts, and differs importantly in linking interest rates and growth. Nonetheless, this paper has benefitted substantially from access to Roberts' preliminary draft. 
overvaluation in equity markets in the late 1990 s. $^{5}$

Glassman and Hassett (1999a,1999b) have gone considerably farther and argued that the large equity premium observed historically reflected unwarranted pessimism regarding the riskiness of stocks and that the equity premium has dropped below historical averages. According to Siegel (1999), the real return to Treasury bills and bonds in the postwar period has averaged about 1 percent, which implies that the equity premium has been in excess of 6 percentage points per year. It is well-known that considerable effort and modifications of typical asset-pricing models are required to generate such a large equity premium (Cochrane (1997)), leading Glassman and Hassett to conclude that perhaps such a large premium will not be required in the future. While their presentation is somewhat stylistic and geared towards a general audience, more academic commentaries have presented similar musings--albeit less forcefully (such as Cochrane (1997) and Heaton and Lucas (1999)). In any event, Glassman and Hassett cite recent research by Claus and Thomas (1999a, 1999b) that suggests the required return to equity is now about 4 percent--a 3 percentage-point equity premium. Inserting such a value for $r$ with $g$ equal to 3 percent implies an equilibrium with a dividend-price ratio near 1--below the reading in 1998. A higher value for g leads to even greater optimism.

Finally, while much of the recent discussion of the market value of firms has followed the tradition outlined above, a recent paper by Robert Hall (1999) has taken a different approach. Hall notes that the market value of firms equals the value of capital owned by those firms. Given the recent rise in the market value of firms discussed in the introduction, Hall argues that investment in intangible capital has been very strong in recent years; of course, supporting data is by definition unavailable. Moreover, it is unclear why growth in the stock of intangible capital should have grown so fast in recent years despite the moderate growth in physical capital recorded over the same period; absent large shifts in the relative price of intangibles, movements in intangible capital and tangible capital should be roughly similar as discussed in Prescott (1997) and the appendix. Given these difficulties, intangible capital is ignored below, and the

${ }^{5}$ Carlson (1999), Heaton and Lucas (1999), and IMF (1999a,1999b) provide tables that consider a broad range of possible values for $r$ and $g$ that illustrate the types of values needed to explain recent equity values. 
remaining sections focus on the possibility that a drop in the required return to equity or an increase in the growth rate lies behind recent increases in the market value of firms in a prototypical general equilibrium model.

\section{A General Equilibrium Model}

A typical representative agent, dynamic general equilibrium model provides a simple framework within which one can examine the impact of fundamentals on a broad range of economic variables--including the market value of firms, investment, output, and the capital stock.

\section{Consumers}

The representative consumer has preferences $(\mathrm{U})$ at time $\mathrm{t}$ given by

$$
\mathrm{U}(\mathrm{C}(\mathrm{t}), \mathrm{L}(\mathrm{t}))=\mathrm{E}_{\mathrm{t}}\left[\sum_{\mathrm{j}=\mathrm{t}}^{\infty} \mathrm{B}^{\mathrm{j}-\mathrm{t}}\left\{\left[\mathrm{C}(\mathrm{j})^{\mathrm{b}} \mathrm{L}(\mathrm{j})^{1-\mathrm{b}}\right]^{1-\mathrm{s}} /(1-\mathrm{s})\right\}\right]
$$

where $\mathrm{E}$ is the expectations operator, $\mathrm{C}(\mathrm{t})$ is consumption at time $\mathrm{t}, \mathrm{L}(\mathrm{t})$ is leisure at time $\mathrm{t}, \mathrm{B}$ is the time discount factor, and $b$ and s are preference parameters. ${ }^{6}$ The consumer is endowed with one unit of time and receives income from wages $(\mathrm{W})$ and equity (or capital) holdings $((\mathrm{Q}+\mathrm{D}) \mathrm{K}$, where $\mathrm{Q}$ is the price of capital, D is the dividend received on a unit of capital, and $\mathrm{K}$ is the quantity of capital), yielding the following constraints on time and consumption purchases:

$$
\begin{aligned}
& \mathrm{L}(\mathrm{t})=1-\mathrm{N}(\mathrm{t}) \\
& \mathrm{C}(\mathrm{t})+\mathrm{Q}(\mathrm{t}) \mathrm{K}(\mathrm{t}+1)=(\mathrm{Q}(\mathrm{t})+\mathrm{D}(\mathrm{t})) \mathrm{K}(\mathrm{t})+\mathrm{W}(\mathrm{t}) \mathrm{N}(\mathrm{t}) .
\end{aligned}
$$

The first constraint describes the relationship between leisure (L) and hours of work $(\mathrm{N})$, while the second describes the possible allocations of income from work and equity holdings into current consumption or equity holdings carried into the next period. Note that equity carried into the next period $(\mathrm{K}(\mathrm{t}+1))$ is purchased at the price of equity in period $\mathrm{t}(\mathrm{Q}(\mathrm{t}))$.

Maximization of (2.1) with respect to $\mathrm{C}, \mathrm{N}$, and $\mathrm{K}$ subject to (2.2) and (2.3) yields the familiar first-order conditions (where $\mathrm{U}_{\mathrm{x}}$ is the partial derivative of $\mathrm{U}$ with respect to $\mathrm{x}$ )

$$
\begin{aligned}
& \mathrm{U}_{\mathrm{C}}(\mathrm{t})=\lambda(\mathrm{t}) \\
& \mathrm{U}_{\mathrm{L}}(\mathrm{t})=\lambda(\mathrm{t}) \mathrm{W}(\mathrm{t})
\end{aligned}
$$

\footnotetext{
${ }^{6}$ In the limiting case where s approaches one, the utility function in (2.1) reduces to $b \log (C(j))+(1-b) \log (L(j))$.
} 


$$
\lambda(\mathrm{t})=\mathrm{B} \mathrm{E}_{\mathrm{t}}[\lambda(\mathrm{t}+1)(1+\mathrm{r}(\mathrm{t}+1))]
$$

where $\lambda(t)$ is the lagrange multiplier on constraint $(2.3)$ and $(1+r(t+1))=(Q(t+1)+D(t+1)) / Q(t)$. These equations are well-known; for example, combining (2.4) and (2.5) yields an expression describing the relationship between consumption and leisure and the real wage, and combining (2.5) and (2.6) describes the relationship between current and future consumption and the return to equity.

\section{Firms}

Firms produce output with labor and capital. In addition, firms face investment adjustment costs that slow capital stock adjustment in response to fundamentals (as developed by Eisner and Strotz (1963), Lucas (1967), and Hayashi (1982)) and drive a wedge between the price of investment and the marginal value of capital--generating fluctuations in Tobin's Q that are key in linking a model's implications for investment and capital accumulation with movements in the market value of firms (as emphasized in Christiano and Fisher (1995), for example). ${ }^{7}$

The production function is given by

$$
\mathrm{Y}=\mathrm{K}(\mathrm{t})^{\mathrm{a}}(\mathrm{Z}(\mathrm{t}) \mathrm{N}(\mathrm{t}))^{1-\mathrm{a}}-\mathrm{C}[\mathrm{I}(\mathrm{t}) / \mathrm{K}(\mathrm{t})] \mathrm{K}(\mathrm{t})
$$

where $\mathrm{C}[\mathrm{I}(\mathrm{t}) / \mathrm{K}(\mathrm{t})] \mathrm{K}(\mathrm{t})$ is an investment adjustment cost function. The adjustment cost function is linearly homogenous in I and $\mathrm{K}$, implying that marginal Q will equal average Q (Hayashi (1982)). The capital accumulation constraint facing firms is given by

$$
\mathrm{K}(\mathrm{t}+1)=\mathrm{I}(\mathrm{t})+(1-\mathrm{d}) \mathrm{K}(\mathrm{t})
$$

Firms maximize the present discounted value of payouts (or dividends)

$$
\mathrm{E}_{\mathrm{t}}\left[\sum_{\mathrm{j}=\mathrm{t}}^{\infty} \prod_{\mathrm{k}=\mathrm{t}}^{\mathrm{j}}(1+\mathrm{r}(\mathrm{k}))^{\mathrm{t}-\mathrm{k}}\{\mathrm{Y}(\mathrm{t})-\mathrm{I}(\mathrm{t})-\mathrm{W}(\mathrm{t}) \mathrm{H}(\mathrm{t})\}\right.
$$

where $r$ is the required return to equity defined above.

Profit maximization yields the standard first-order conditions for N, I, and $\mathrm{K}$

$$
(1-a) K(t)^{a} Z(t)^{1-a} N(t)^{-a}=W(t)
$$

${ }^{7}$ For tractability, these references focus on convex adjustment costs; recent research has emphasized non-convexities in adjustment costs (e.g., Dixit and Pindyck (1994) and Caballero (1997)). Partial equilibrium models of adjustment costs and equity prices can be found in Cochrane (1997) and Roberts (1999), who explore the relationship between investment and equity returns in a "production-based asset pricing model". 


$$
\begin{aligned}
& 1+\mathrm{C}_{\mathrm{I}}[\mathrm{I}(\mathrm{t}) / \mathrm{K}(\mathrm{t})]=\mathrm{Q}(\mathrm{t}) \\
& \mathrm{E}_{\mathrm{t}}[1+\mathrm{r}(\mathrm{t}+1)]^{-1}\left\{\mathrm { a } \left(\mathrm{~K}(\mathrm{t}+1)^{\mathrm{a}-1}(\mathrm{Z}(\mathrm{t}+1) \mathrm{H}(\mathrm{t}+1))^{1-\mathrm{a}}-\mathrm{C}[\mathrm{I}(\mathrm{t}+1) / \mathrm{K}(\mathrm{t}+1)]+\right.\right. \\
& \left.\quad \mathrm{C}_{\mathrm{I}}[\mathrm{I}(\mathrm{t}+1) / \mathrm{K}(\mathrm{t}+1)] \mathrm{I}(\mathrm{t}+1) / \mathrm{K}(\mathrm{t}+1)\right\}=\mathrm{Q}(\mathrm{t})-\mathrm{E}_{\mathrm{t}}[1+\mathrm{r}(\mathrm{t}+1)]^{-1}(1-\mathrm{d}) \mathrm{Q}(\mathrm{t}+1)
\end{aligned}
$$

These conditions equate the marginal product of labor to the real wage, the marginal cost of a unit of capital to its marginal value, and the marginal product of capital to its return, including capital gains and net of depreciation.

\section{Calibration}

In order to evaluate the quantitative implications of the model, parameter values must be assigned. The initial parameter values are presented in panel A of table 1. For preferences, I assume "s" equals one, implying log preferences over consumption and leisure. The value of "b" (0.25) implies that about $1 / 4$ of the time endowment is spent at work. These values are widely used in the literature.

The return on equity is a key variable in the model. As is typical in general equilibrium models of this type, it is difficult in the model presented above to generate a return on equity that is substantially above the risk-free return in the economy. The failure of the model to generate a large equity premium arises because the return on a risky asset in the model reflects consumption risk (through equations (2.4) and (2.6)), and the modest variability in consumption observed in the data--combined with the relatively weak degree of risk aversion implied by log utility--yields a tiny equity premium (see Cochrane (1997) for exhaustive references). Therefore, the return to equity (r) is simply set to 7.5 percent in the nonstochastic steady state, about the value in the postwar period. This restriction, combined with equation (2.6), the coefficient of relative risk aversion (s), and an assumption about the growth rate (discussed below) tie down the time discount factor (B). Shifts in required returns are modeled as changes in the time-discount factor (B)--so, for example, recent discussion of a lower required return is introduced in the model by assuming people have become more long-sighted. While some authors have attempted to model the shift in the required return as a function of changing attitudes towards risk or increased diversification of portfolios due to financial innovations (Heaton and Lucas (1999)), such attempts have been relatively unsuccessful (again, reflecting the difficulty in generating a significant equity premium puzzle in models with endogenous consumption and interest rates). 
Given these difficulties, movements in the required return reflect movements in B--as in one case considered by Heaton and Lucas (1999), who suggest increased longevity has lowered the time discount rate. This assumption does not bias the results below in any obvious way.

The adjustment cost function takes the form

$$
\mathrm{C}[\mathrm{I}(\mathrm{t}) / \mathrm{K}(\mathrm{t})] \mathrm{K}(\mathrm{t})=0.5 \mathrm{c}(\mathrm{I}(\mathrm{t}) / \mathrm{K}(\mathrm{t})-\mathrm{x})^{2} \mathrm{~K}(\mathrm{t})
$$

where $\mathrm{c}$ and $\mathrm{x}$ are parameters. ${ }^{8} \mathrm{I}$ assume that adjustment costs are zero when investment is at its steady-state level ( $\mathrm{x}=\mathrm{g}+\mathrm{d}$, where $\mathrm{g}$ is the steady-state growth rate), and consider a range of values for $\mathrm{c}$ below. The capital share of income in the steady-state is set between one quarter and one third $(\mathrm{a}=0.282)$, and $\mathrm{Z}$ grows at an exogenous rate $\mathrm{g}(\mathrm{Z}(\mathrm{t})=(1+\mathrm{g}) \mathrm{Z}(\mathrm{t}-1))$. For convenience, $\mathrm{I}$ set $\mathrm{g}=0$ initially, although the results do not depend on considering a steady state without growth. Finally, the depreciation rate is set at 6.6 percent, a standard value. These parameter values completely describe the steady state, as the remaining parameters are determined by the restrictions implied by the first-order conditions and constraints.

As shown in the bottom row of panel A, these restrictions imply that the capital-output ratio is two and the investment rate $(\mathrm{I} / \mathrm{Y})$ is about 13 percent. By way of comparison, the (nominal) capital-output ratio for the nonfarm business sector over 1958-1993 averaged 1.98 and the (nominal) investment rate (I/Y) averaged 13.2 percent. $^{9}$

\section{Table 1: Initial Parameters}

\begin{tabular}{|c|c|c|c|c|c|}
\hline \multicolumn{7}{|c|}{ Key Parameters in Initial Steady State } \\
\hline $\mathrm{s}=1$ & $\mathrm{~b}=0.25$ & $\mathrm{a}=0.282$ & $\mathrm{r}=0.075$ & $\mathrm{~B}=0.93$ & $\mathrm{~d}=0.066$ \\
\hline $\mathrm{c}=$ various values & $\mathrm{x}=0.066$ & $\mathrm{~g}=0.0$ \\
\hline \multicolumn{3}{|c|}{ Key Ratios in Initial Steady State } \\
\hline
\end{tabular}

${ }^{8}$ This form of adjustment cost function has been widely used in the empirical literature (see references). Of course, this form should simply be viewed as a restricted second-order approximation of a more general specification.

${ }^{9}$ Note that these values are based on the data that is consistent with the BLS multifactor productivity release of 1999--which pre-dated the revision to the national accounts that added investment in software to business fixed investment (in October, 1999). See footnote 10 below. 


\section{Implications of a Drop in the Required Return}

The initial steady state is perturbed by assuming an increase in the discount factor that lowers the required return to equity to 0.04 percent--the value suggested by Glassman and Hassett (1999a,1999b) and Claus and Thomas (1999a,1999b). The remaining parameters remain the same. The drop in the equity premium leads to a large shift in the capital-output ratio and investment share of output in the new steady state; these changes occur through equation (2.12)-i.e., the lower required marginal product of capital encourages capital investment--and equation (2.8)--i.e., a larger capital stock requires greater investment.

Table 2: Final Parameters

\begin{tabular}{|c|c|c|c|c|c|}
\hline \multicolumn{7}{|c|}{ Key Parameters in Final Steady State } \\
\hline $\mathrm{s}=1$ & $\mathrm{~b}=0.25$ & $\mathrm{a}=0.282$ & $\mathrm{r}=0.04$ & $\mathrm{~B}=0.962$ & $\mathrm{~d}=0.066$ \\
\hline $\mathrm{c}=$ various values & \multicolumn{3}{|c|}{$\mathrm{x}=0.066$} & $\mathrm{~g}=0.0$ \\
\hline \multicolumn{3}{|c|}{ Key Ratios in Initial Steady State } \\
\hline
\end{tabular}

Figures 2 through 4 present the dynamic implications of a drop in the required return to equity. In each figure, the economy is initially in a steady-state, and the required return to equity falls to 4 percent. The exact results depend upon the level of investment adjustment costs. The figures consider three values for adjustment costs: no adjustment costs $(\mathrm{c}=0.0)$, moderate adjustment costs $(c=15$, which implies an elasticity of $\mathrm{I} / \mathrm{K}$ with respect to $\mathrm{Q}$ near 1 , about the value found in recent work by Cummins, Hassett, and Oliner (1999)), and high adjustment costs ( $c=30$, which implies an elasticity of $\mathrm{I} / \mathrm{K}$ with respect to $\mathrm{Q}$ of about $1 / 2$--similar to traditional estimates of large adjustment costs, i.e. Abel (1980), Summers (1981), and Chirinko (1993)).

Focusing first on the qualitative patterns, figures 2 through 4 paint a uniform picture of the response of the economy to the shift in the equity premium: output and investment rise, with investment rising by a greater amount than output (I/Y increases), and the capital stock begins to grow rapidly. Depending on the value of adjustment costs, the marginal value of capital (Q) also rises sharply, and the market value of capital rises considerably over the first five years following 
the shift in the required return. These dynamics follow because the lowering of the required return to equity implies that capital can earn a lower marginal product and still satisfy the return requirements of investors. Since the marginal product of capital is fixed in the short-run, the initial response of the economy is an increase in the marginal value of capital and a period of faster growth in the capital stock. In the long run, the supply of capital is perfectly elastic in a production economy, so the marginal value of capital returns to one, and the capital stock is permanently higher (and hence has a lower marginal product).

These results are qualitatively quite different from those of an endowment economy with exogenous dividends as considered in Heaton and Lucas (1999) or exercises using the Gordon growth model. With a fixed capital stock and dividend flow, prices--or the marginal value of capital--reacts to the change in required return in those models, but production and investment do not. Obviously, focusing on the Gordon model limits the range of implications of a drop in required returns; perhaps more sinisterly, use of the Gordon model masks the links between the dividend flow, investment opportunities at the firm, and the costs of financing investment projects (i.e., required returns), and hence obscures the testable implications of shifts in required returns.

To see more clearly how using the Gordon model masks the range of quantitative predictions that follow from a drop in required returns, table 3 presents some data on the performance of the economy over the last five years (1994-1998), along with the predictions of the alternative calibrations of the model. 
Table 3: Recent Data and Model Predictions (percent change)*

\begin{tabular}{|c|c|c|c|c|c|}
\hline Variable & 1994-1998 & $\begin{array}{l}\text { Detrended } \\
1994-1998\end{array}$ & $\begin{array}{l}\text { No Adjust. } \\
\text { Costs }\end{array}$ & $\begin{array}{l}\text { Moderate } \\
\text { Adjust. Costs }\end{array}$ & $\begin{array}{l}\text { High Adjust. } \\
\text { Costs }\end{array}$ \\
\hline Output & 19.7 & 4.9 & 14.4 & 5.4 & 3.6 \\
\hline Investment & 31.6 & 29.3 & 76.7 & 33.0 & 23.1 \\
\hline I/Y (level) & 12.3 & 12.3 & 29.5 & 17.4 & 15.9 \\
\hline K & 7.4 & 0.4 & 26.7 & 9.2 & 6.3 \\
\hline $\mathrm{Q}$ & 58.2 & 58.2 & 0.0 & 23.5 & 33.2 \\
\hline QK & 65.6 & 58.6 & 26.7 & 32.7 & 39.5 \\
\hline
\end{tabular}

${ }^{*}$ Model predictions are growth over first five years of simulation (100*log differences), or average over first five years in case of $\mathrm{I} / \mathrm{Y}$. Variables are detrended with their average growth rate over 1984-1993, except for I/Y and Q--which have no trend in the model and hence are not detrended.

While the qualitative response of the economy is relatively independent of the parameterization of adjustment costs, the quantitative predictions depend on the parameters chosen. The parameter values in the moderate adjustment cost case provide the best match to the growth rates of investment and output, so the discussion will focus primarily on this case. However, the results are broadly similar across parameterizations.

Looking first at the match between the predictions for output and investment and the data, the correspondence is pretty good; the model predicts an acceleration of investment of about 30 percent and a pickup in output near 5 percent, and these values are about what happened in the data over the 1994-1998 period. The model also predicts a substantial runup in the market value of capital--a little over 30 percent. This value is half the growth in the market value of the nonfarm business sector over that period, suggesting that the model can account for about half the runup in market values. As a benchmark for comparison, in the Gordon growth model with $r$ and g initially equal to 7.5 percent and 0.0 percent, respectively, the formula above implies that the market value of firms would rise 59.6 percent if $r$ fell to 4 percent and dividends were unchanged, almost exactly the change in the market value of firms in the data.

This difference in the degree of increase in market value between the baseline general 
equilibrium model and the Gordon growth model provides one important example of the lessons one can learn by considering the implications of changes in required returns in a model with production. To see this a bit more clearly, a little algebra and a description of steady-state behavior is useful. First, recall that the market value of firms in the Gordon growth model with a constant interest rate and growth rate is given by

$$
\mathrm{V}=\mathrm{D} /(\mathrm{r}-\mathrm{g}) \text {. }
$$

The same equation applies in the general equilibrium model, but here payouts are determined endogenously and equal the difference between output (revenues) and investment and wage payments

$$
\mathrm{D}=\mathrm{Y}-\mathrm{I}-\mathrm{WH} \text {. }
$$

Along a steady-state growth path, I equals $(\mathrm{g}+\mathrm{d}) \mathrm{K}$ (replacement investment plus investment for growth) and, given the Cobb-Douglas production function, WH equals (1-a)Y and the capitaloutput ratio equals $\mathrm{a} /(\mathrm{r}+\mathrm{d})$. Therefore, dividends as a share of output equal

$$
\mathrm{D} / \mathrm{Y}=\mathrm{a}-(\mathrm{g}+\mathrm{d}) \mathrm{K} / \mathrm{Y}=\mathrm{a}-\mathrm{a}(\mathrm{g}+\mathrm{d}) /(\mathrm{r}+\mathrm{d})=\mathrm{a}(\mathrm{r}-\mathrm{g}) /(\mathrm{r}+\mathrm{d}),
$$

and hence the ratio of the market value of firms to output equals

$$
\mathrm{V} / \mathrm{Y}=\mathrm{a} /(\mathrm{r}+\mathrm{d}) \text {. }
$$

In the Gordon model, a decrease in $r$ raises the market value of firms by the same amount it decreases (r-g) (from (3.1))--which, in percentage terms, can be quite large as the interest rate approaches the growth rate. In contrast, the ratio of the market value of firms to output only rises in response to a permanently lower required return by the percentage that $(r+d)$ decreases (from (3.2)), which--for positive depreciation rates--is much smaller than the percentage decrease in ( $\mathrm{r}$ g). What is the economics behind this algebra? A lower required return makes more investment projects profitable, implying an increase in the investment share of output and a decrease in the dividend share. Consequently, the market value of firms rises much less in a production economy than in the Gordon growth model.

A second lesson can be seen in comparing the predictions of the model for the level of the investment ratio (I/Y) and for capital stock growth with developments in the data. As is clear in figures 2 through 4 or the last two columns of table 3, incorporating investment adjustment costs into the analysis substantially mutes the response of investment to the capital shortage, but the 
response remains considerable. Therefore, the model implies that the investment share of output should rise strongly and the capital stock should grow rapidly. Even with large adjustment costs, the model expects the capital stock to rise by more than 6 percent over the first five years following the drop in the required return to equity and the investment ratio to rise to near 16 percent of output. The data tell a different story, with the capital stock (deflated by output prices) barely growing and the investment ratio below its long-term average in the 1990s. The belowaverage share of investment in the nonfarm business sector in the late 1990s may be surprising given press reports discussing the strength of investment in recent years, but this strength probably reflects the strong cyclical position of the economy in the last couple of years. Figure 5 presents a graph of the share of investment in equipment and structures in the nonfarm business sector and the share of business fixed investment in GDP since the late 1950s. Both graphs illustrate the volatility of the ratio, and the high share reached by 1998 ; however, looking at the average share over the entire period of strong growth in the market value of firms (1994-1998) reveals that the investment share has not deviated from its historical range. ${ }^{10}$

The failure to find any pickup in the investment share of output in the data is a serious blow to the notion that increased investor patience or increased risk tolerance are leading to an increased willingness of investors to hold risky assets. The data suggest that firms are not increasing investment in the face of lower required returns, and if anything investment remains low relative to output when compared to historical averages. Hence, the surge in the market value of firms in the late 1990s, while qualitatively consistent with the notion that the required return to equity has fallen, does not appear to be consistent with the implications of a typical general equilibrium model when the implications outside of financial markets are considered.

${ }^{10}$ The share for the nonfarm business sector does not incorporate the recent inclusion of software in investment (as those data are not yet available), but the GDP share does incorporate software. As is clear from the bottom panel of figure 5, incorporating software leads to a higher average share since the 1970s (relative to the previous period), but does not alter the pattern in recent years. Between 1974 and 1993, business fixed investment was, on average, 11.6 percent of GDP; between 1994 and 1998, business fixed investment averaged 11.5 percent of GDP. 


\section{Implications of an Increase in the Growth Rate}

The model can also be used to examine the effect of a faster growth rate on the market value of firms. First, recall that the Gordon growth model implies that the market value of firms is given by

$$
\mathrm{V}=\mathrm{D} /(\mathrm{r}-\mathrm{g})=\mathrm{pY} /(\mathrm{r}-\mathrm{g})
$$

where $\mathrm{p}$ is the payout rate and hence $\mathrm{pY}$ is dividends. To generate a ratio of market value to output of two at the baseline parameter values in table $1(\mathrm{r}=0.075, \mathrm{~g}=0)$ requires a payout rate of 15 percent (which is identical to the share of payouts in the baseline general equilibrium model, where payouts (Y-I-WH) equal 15 percent of output in the initial steady state described in table 1). Permanent changes in the growth rate can have a powerful effect on market values in the Gordon model, as increases in g--with a fixed interest rate r--can generate large percent changes in $\mathrm{r}-\mathrm{g}$.

The general equilibrium model delivers quite a different result. First, consider equation (2.6); in the steady state, this condition (with $\mathrm{s}=1$ ) implies that the return required by consumers is

$$
\mathrm{r}=-\log (\mathrm{B})+\mathrm{g} .
$$

If $\mathrm{s}$ is greater than 1, the return increases even more with growth, reflecting consumers decreased willingness to substitute intertemporally. ${ }^{11}$

Equation (2.12) implies that in a steady state where $\mathrm{Q}$ equals one and s equals one

$$
\mathrm{aY} / \mathrm{K}=\mathrm{r}+\mathrm{d}=-\log (\mathrm{B})+\mathrm{g}+\mathrm{d} .
$$

This equation illustrates a key difference between a production economy with an endogenous interest rate and models with an exogenous interest rate, as this equation shows that an increase

${ }^{11}$ Specifically, holding leisure constant, equation (2.6) shows that the intertemporal elasticity of substitution along a steady-state path is given by $-1 /[\mathrm{b}(1-\mathrm{s})-1]$. A lower intertemporal elasticity of substitution--say around 0.2 --implies much greater sensitivity of the required return to growth, as a decreased willingness to substitute future for current consumption implies less current savings when future consumption is expected to be high. The optimizing behavior of consumers combined with low estimates of intertemporal elasticities of substitution is not the only theory expecting a strong relationship between interest rates and growth: For example, the interest rate is likely to rise more than one-for-one with the growth rate in a Solow growth model with an exogenous, fixed savings rate. 
in the growth rate of the economy actually lowers the ratio of capital (or market value) to output in the steady state. Thus, an increase in the growth rate of the economy, absent shifts in the equity premium as discussed in section 3, cannot explain the surge in market value shown in the data in recent years; the model predicts a response of the opposite sign for the ratio of market value to output. This prediction seems quite reasonable, as it stems from the notion that an increase in growth makes people less willing to postpone current consumption for future consumption (which will already be higher because of growth) and hence raises the interest rate in the economy and lowers the ratio of capital to output. One should note, however, that empirical evidence is somewhat equivocal on the link between interest rates and consumption growth ${ }^{12}$--so the theoretical prediction of a drop in the ratio of market value to output following an increase in the growth rate may not be a good description of the data. Nonetheless, the theory does not predict an increase in the ratio of market value to output unless the interest rate falls when the growth rate increases--an outcome that is not theoretically possible in typical models.

One can also show that the capital accumulation equation implies that $\mathrm{I} / \mathrm{K}=\mathrm{g}+\mathrm{d}$,

yielding a steady-state investment share of

$$
\mathrm{I} / \mathrm{Y}=\mathrm{a}(\mathrm{g}+\mathrm{d}) /(\mathrm{r}+\mathrm{d}) \text {. }
$$

If $g$ increased 2 percentage points from the baseline value (of zero), the investment intensity of the economy in steady state would rise from 13.2 percent to 15.2 percent--lowering the payout rate from 15 percent to 13 percent. This shift again illustrates how parameters that are held exogenously at historical averages in the Gordon model--such as the payout rate--change in a general equilibrium model when other parameters change, and such changes are important when considering implied changes in market values.

\section{Summary}

The relationship between the market value of firms and fundamentals in a production economy is different than the relationship between the market value of firms and fundamentals in

\footnotetext{
${ }^{12}$ See, for example, the literature survey on the Consumption CAPM in Cochrane (1997).
} 
typical calculations using the Gordon growth model. Explicitly modeling the interaction between production decisions and fundamentals such as the required return to equity or the growth rate of the economy is important both for quantitative and qualitative evaluation of different hypotheses explaining movements in the market value of firms.

Comparison of the conclusions of this paper with that of some other recent research highlights the importance of considering production. Both Siegel (1999) and Glassman and Hassett (1999a,1999b) suggest that the recent surge in the market value of the nonfarm business sector is not a signal of investor's "irrational exuberance", but rather reflects a decline in the required return to equity and/or an increase in growth. It is straightforward to see that their claims are quite reasonable in the Gordon growth model, if one is willing to entertain permanent shifts in the relevant fundamentals (although many are skeptical of such permanent shifts, such as Campbell and Shiller (1998) and Carlson (1999)). Of course, the Gordon model was meant to describe a relationship between a single firm's earnings, dividends, and required returns--not the general equilibrium determination of interest rates, investment, and growth prospects for the entire economy.

Consideration of these general equilibrium effects overturns key implications of the Gordon model. In a model with production, a drop in the required return to equity spurs capital accumulation (as firms find previously marginal projects are now profitable). The process of capital accumulation requires increased investment and hence greater retained earnings and lower dividends. Because of this process, the increase in the market value of firms from a shift in the required return to equity in a production economy is lower than the increase in the Gordon model. In the quantitative exercises above, a drop in the required return to equity generates an increase in the market value of firms about half that observed in the recent data--leaving ample room for a role of "irrational exuberance" (or, perhaps, other shifts in fundamentals that have not been widely considered). Further, the model above illustrated how the links between interest rates and growth imply that faster growth can actually lower the ratio of the market value of firms to output--a prediction of opposite sign from the typical result derived in the Gordon growth model.

Finally, consideration of a production economy illustrates the wide-ranging implications 
of a drop in the required return to equity or an increase in the growth rate of productivity. One implication of a drop in required returns is an increase in the investment share of output. Such an increase simply reflects the relationship between the willingness to hold capital (which increases when the required return falls) and the supply of capital available for production (which increases when demand increases because supply is elastic in the long-run). Recent data do not indicate that the investment intensity of the economy has risen notably when compared to historical averages, and therefore do not provide support to the idea that the surge in market values reflects a large drop in the required return. 


\section{References}

Abel, Andrew (1980) Empirical Investment Equations: An Integrative Approach. CarnegieRochester Conference Series on Public Policy 12:39-91.

Caballero, Ricardo (1997) Aggregate Investment. NBER Working Paper 6264.

Campbell, John Y., and Robert E. Shiller (1998) Valuation Ratios and the Long-Run Stock Market Outlook. Journal of Portfolio Management 24:11-26.

Carlson, John (1999) The Recent Ascent in Stock Prices: How Exuberant Are You?. Mimeo, Federal Reserve Bank of Cleveland (September).

Chirinko, Robert S. (1993) Business Fixed Investment Spending: A Critical Survey of Modeling Strategies, Empirical Results, and Policy Implications. Journal of Economic Literature 31:1875-1911.

Christiano, Lawrence J. and Jonas Fisher (1995) Tobin's q and Asset Returns: Implications for Business Cycle Analysis. NBER Working Paper 5292.

Claus, James and Jacob Thomas (1999a) The Equity Risk Premium Is Much Lower Than You Think It Is: Empirical Estimates from a New Approach. Mimeo, Columbia Business School (May).

Claus, James and Jacob Thomas (1999b) Measuring the Equity Premium Using Earnings Forecasts: An International Analysis. Mimeo, Columbia Business School (June).

Cochrane, John H. (1997) Where is the market going? Uncertain facts and novel theories. Federal Reserve Bank of Chicago Economic Perspectives (November/December).

Cummins, Jason, Kevin Hassett and Stephen Oliner (1999) Investment Behavior, Observable Expectations, and Internal Funds. Federal Reserve Board FEDS Paper 1999-27.

Dixit, Avinash, and Robert Pindyck (1994) Investment Under Uncertainty. Princeton University Press.

Eisner, Robert, and Robert H. Strotz (1963) Determinants of Business Investment. In Commission on Money and Credit: Impacts of Monetary Policy. Prentice Hall. Glassman, James K., and Kevin A. Hassett (1999a) Dow 36,000.Times Books.

Glassman, James K., and Kevin A. Hassett (1999b) Bubbloney. On The Issues. American Enterprise Institute (October). 
Gordon, M. (1962) The Investment, Financing, and Valuation of the Corporation. Irwin.

Hall, Robert E. (1999) The Stock Market and Capital Accumulation. NBER Working Paper 7180.

Hayashi, Fumio (1982) Tobin's Marginal and Average q: A Neoclassical Interpretation. Econometrica 50:213-224.

Heaton, John and Deborah Lucas (1999) Stock Prices and Fundamentals. NBER Macroeconomics Annual.

IMF (1999a) The International Capital Markets Report.

IMF (1999b) The World Economic Outlook.

Kiley, Michael T. (1999) Computers and Growth with Costs of Adjustment: Will the Future Look Like the Past? Federal Reserve Board FEDS Paper 1999-36.

Lucas, Robert E. (1967) Adjustment Costs and the Theory of Supply. Journal of Political Economy 75:321-334.

Prescott, Edward C. (1997) Needed: A Theory of Total Factor Productivity. Federal Reserve Bank of Minneapolis Research Department Staff Report 242.

Roberts, John (1999) Notes on Stock Prices and Adjustment Costs. Mimeo (October).

Siegel, Jeremy (1999) The Shrinking Equity Premium: Historical Facts and Future Projections. In The Equity Premium and Stock Market Valuations. Conference Proceedings, Anderson School at UCLA.

Summers, Lawrence H. (1981) Taxation and Corporate Investment: A q-Theory Approach. Brookings Papers on Economic Activity 1:67-127. 


\section{Appendix: A Model With Intangible Capital}

Hall (1999) suggests that the runup in the market value of firms in recent years reflects the accumulation of intangible capital. Consider an economy in which the representative firm produces output $(\mathrm{Y})$ according to the (net) production function

$$
\mathrm{Y}=\mathrm{K}^{\mathrm{a}} \kappa^{\mathrm{b}}(\mathrm{H})^{1-\mathrm{a}-\mathrm{b}}-\mathrm{C}_{\mathrm{I}}(\mathrm{I} / \mathrm{K}) \mathrm{K}-\mathrm{C}_{1}(\mathrm{~V} / \kappa) \kappa
$$

where $\mathrm{K}$ represents the stock of physical capital, $\kappa$ represents the stock of intangible capital, and $\mathrm{H}$ represents hours of labor input. $\mathrm{C}_{\mathrm{I}}(.) \mathrm{K}$ is a physical investment adjustment cost function, and $\mathrm{I}$ represents investment in physical capital. $\mathrm{C}_{1}(.) \mathrm{K}$ is an intangible investment adjustment cost function, and $\mathbf{\imath}$ represents investment in intangible capital.

The representative firm faces competitive output and factor markets. The price of final output is denoted by $\mathrm{P}$, and the prices of investment in physical and intangible capital are $\mathrm{P}_{\mathrm{I}}$ and $\mathrm{P}_{1}$, respectively.

The firm's costs include wage payments and purchases of capital assets

$$
\text { Total Costs }=\mathrm{WH}+\mathrm{P}_{\mathrm{I}} \mathrm{I}+\mathrm{P}_{1} \mathrm{l}
$$

where W is the wage rate. Finally, the firm's stocks of capital assets evolve according to

$$
\begin{aligned}
K^{\prime} & =I-d_{I} K \\
\kappa^{\prime} & =1-d_{1} \kappa
\end{aligned}
$$

where $x^{\prime}$ equals $d x / d t$ and $d_{I}\left(d_{1}\right)$ is the depreciation rate of physical (intangible) capital.

The firm maximizes the present discounted value of profits

$$
\int_{0}^{\infty} \mathrm{e}^{-\mathrm{rt}}\left\{\mathrm{P}\left(\mathrm{K}^{\mathrm{a}} \kappa^{\mathrm{b}}(\mathrm{H})^{1-\mathrm{a}-\mathrm{b}}-\mathrm{C}_{\mathrm{I}}(\mathrm{I} / \mathrm{K}) \mathrm{K}-\mathrm{C}_{\mathrm{l}}(\mathrm{V} / \kappa) \kappa\right)-\mathrm{WH}-\mathrm{P}_{\mathrm{I}} \mathrm{I}-\mathrm{P}_{1} \mathrm{l}\right\}
$$

where $r$ is the discount rate or required return.

Maximizing profits with respect to I and $\mathbf{t}$ and the state variables $\mathrm{K}$ and $\kappa$ yields the hamiltonian conditions (plus a transversality condition) ${ }^{13}$

$$
\begin{aligned}
& \left(\mathrm{r}+\mathrm{d}_{\mathrm{I}}\right) \mathrm{Q}_{\mathrm{I}}-\left[\mathrm{aP}\left(\mathrm{K}^{\mathrm{a}-1} \kappa^{\mathrm{b}}(\mathrm{ZEH})^{1-\mathrm{a}-\mathrm{b}}-\mathrm{C}_{\mathrm{I}}(\mathrm{I} / \mathrm{K})+\mathrm{C}_{\mathrm{I}}^{\prime}(\mathrm{I} / \mathrm{K}) \mathrm{I} / \mathrm{K}\right)\right]=\mathrm{Q}_{I}{ }^{\prime} \\
& \mathrm{C}_{\mathrm{I}}^{\prime}(\mathrm{I} / \mathrm{K})+\mathrm{P}_{\mathrm{I}}=\mathrm{Q}_{\mathrm{I}} \\
& \left(\mathrm{r}+\mathrm{d}_{1}\right) \mathrm{Q}_{1}-\left[\mathrm{bP}\left(\mathrm{K}^{\mathrm{a}} \kappa^{\mathrm{b}-1}(\mathrm{ZEH})^{1-\mathrm{a}-\mathrm{b}}-\mathrm{C}_{1}(\mathrm{~V} / \kappa)+\mathrm{C}_{1}^{\prime}(\mathrm{V} / \kappa) \sqrt{ } / \mathrm{\kappa}\right)\right]=\mathrm{Q}_{1}{ }^{\prime} \\
& \mathrm{C}_{1}^{\prime}(\mathrm{V} / \kappa)+\mathrm{P}_{1}=\mathrm{Q}_{1}
\end{aligned}
$$

${ }^{13}$ The condition for $\mathrm{H}$ is ignored, as it is standard and does not affect any of the results. 
where $\mathrm{Q}_{\mathrm{xt}}, \mathrm{x}=\mathrm{I}$ or $\mathbf{1}$, is the costate variable associated with the constraint (a.3); note that $\mathrm{Q}_{\mathrm{xt}}$ represents the marginal value of physical or intangible capital which includes both the purchase price and adjustment costs (see (a.6) and (a.8)).

Observable data is available for $\mathrm{K}, \mathrm{I}$, and $\mathrm{P}_{\mathrm{I}}$, as well as the labor hours that enter (a.5)(a.8). However, $\kappa, \mathbf{l}$, and $\mathrm{P}_{1}$ are not observable--and neither is the split of capital income between physical and intangible capital (i.e., the parameters $\mathrm{a}$ and $\mathrm{b}$, and the parameters of the adjustment cost function). A number of assumptions can overcome the lack of data on intangible capital, however. In particular, if one assumes that the prices of intangible and physical capital move together $\left(\mathrm{P}_{1}=\mathrm{P}_{\mathrm{I}}\right)$ and that adjustment costs and depreciation rates are the same for intangible and physical capital $\left(\mathrm{d}_{1}=\mathrm{d}_{\mathrm{I}}, \mathrm{C}_{1}(\mathrm{x})=\mathrm{C}_{\mathrm{I}}(\mathrm{x})\right)$, then observed movements in physical capital reveal movements in intangible capital and the marginal value of each type of capital (i.e., Q) is identical. To see this, consider a sequence of $\mathrm{K}$ and I that satisfies (a.5) and (a.6); under the conditions described above, the sequences $\kappa_{t}=b K_{t} / a$ and $t_{t}=b I_{t} / a$ satisfy (a.7) and (a.8), revealing the physical investment is proportional to intangible investment. Prescott (1997) considers similar conditions relating physical and intangible capital in order to measure intangible capital from observable quantities in a model without adjustment costs.

Of course, these conditions are strong; there is no particular reason to believe that the price of investment in intangible capital is identical to that of physical capital, and likewise for the other assumptions. However, it is not obvious in what direction such assumptions are likely to bias any results, and the assumptions illustrate a central point; if firms are investing optimally along all margins and the price of investing in physical capital does not change relative to the price of investing in intangible capital, then investment in intangible capital moves with investment in physical capital. This point is important because it suggests that Hall's (1999) attribution of the sharp rise in equity values during the 1990s to an increase in the stock of intangible capital during a period of relatively slow growth in the stock of physical capital is only plausible if in fact the relative price of investment in intangible capital has fallen significantly. 


\section{Figure 1 \\ Market Value of Firms and Value of Physical Capital}
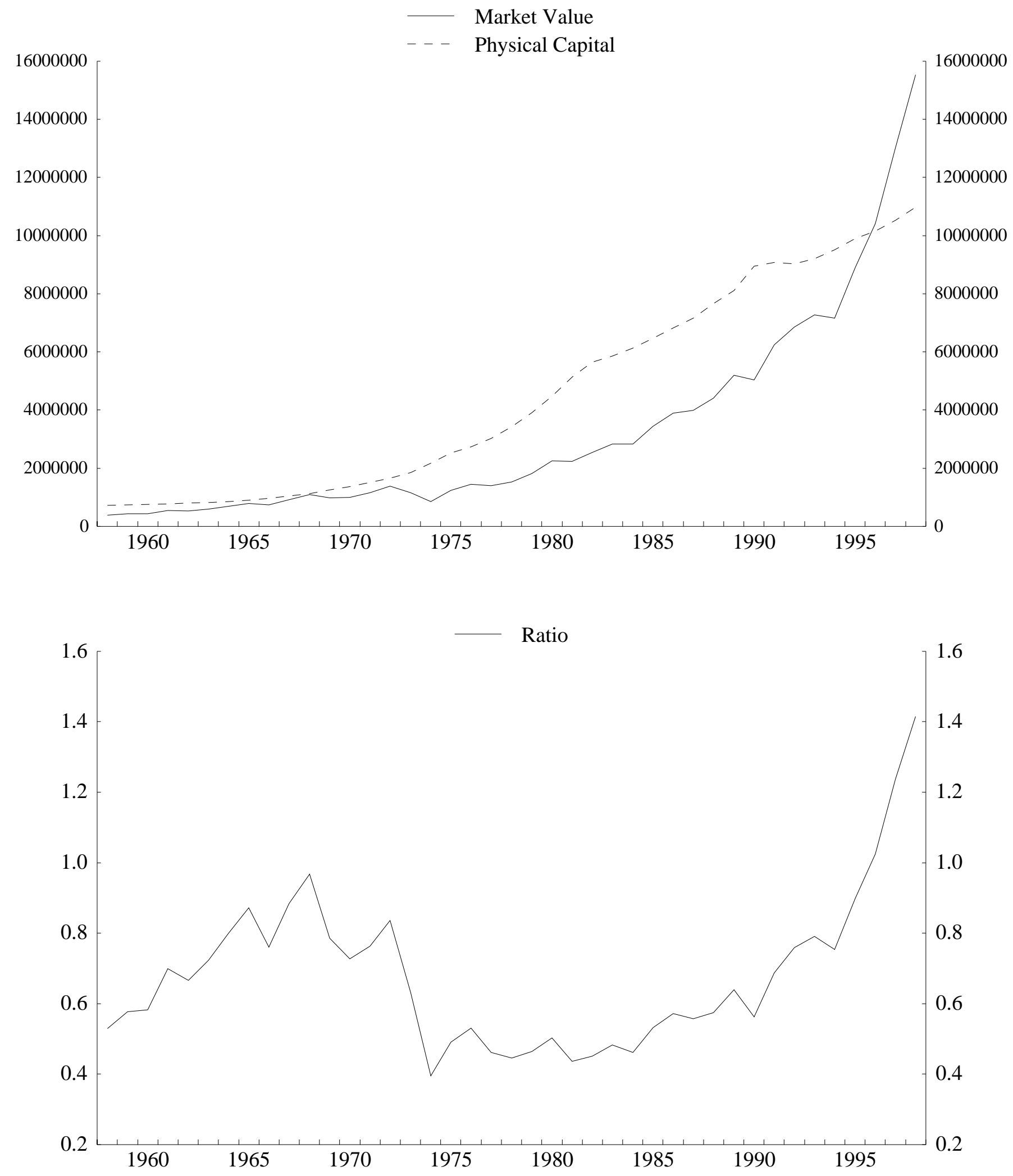
Figure 2A

Dynamics with No Adjustment Costs

Investment

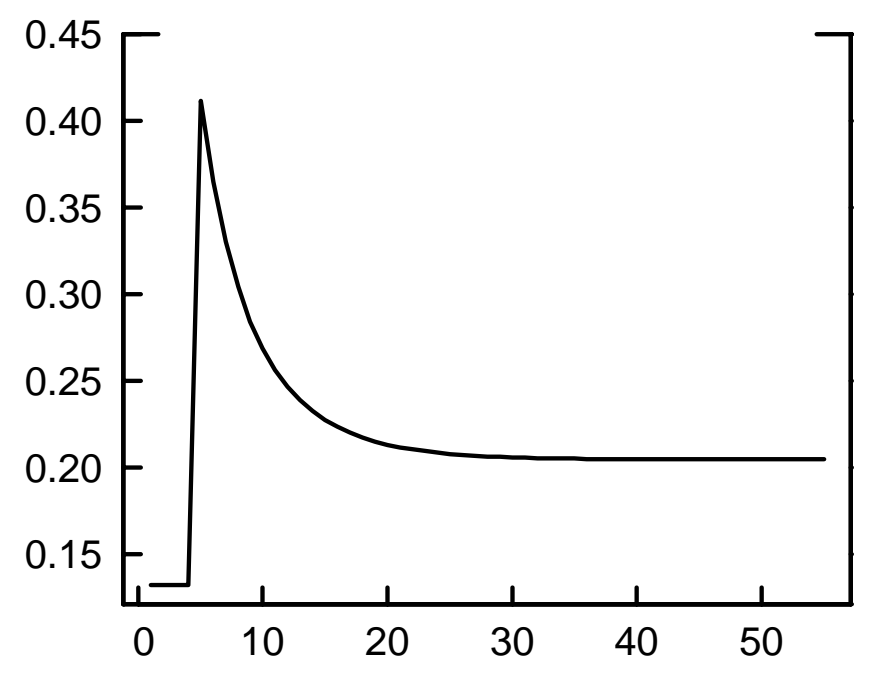

Output

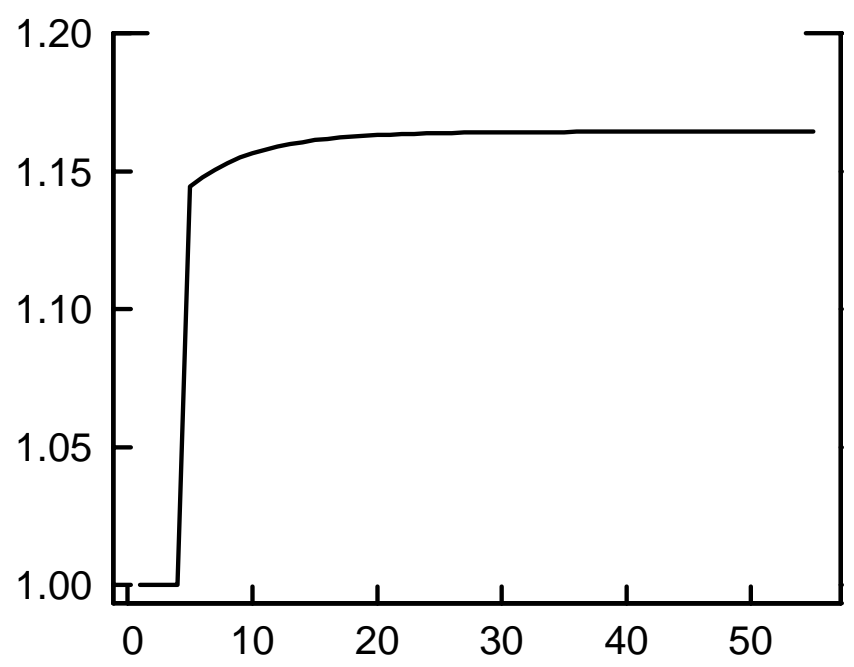

Investment Rate

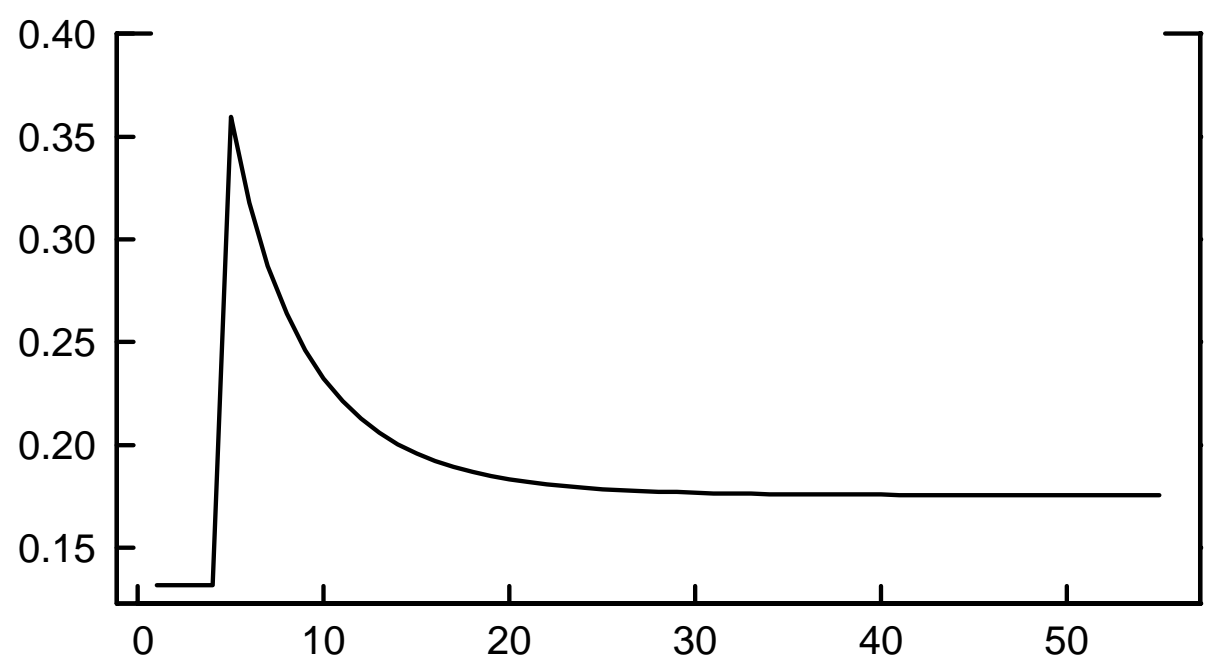


Figure 2B

Dynamics with No Adjustment Costs

Price of Capital

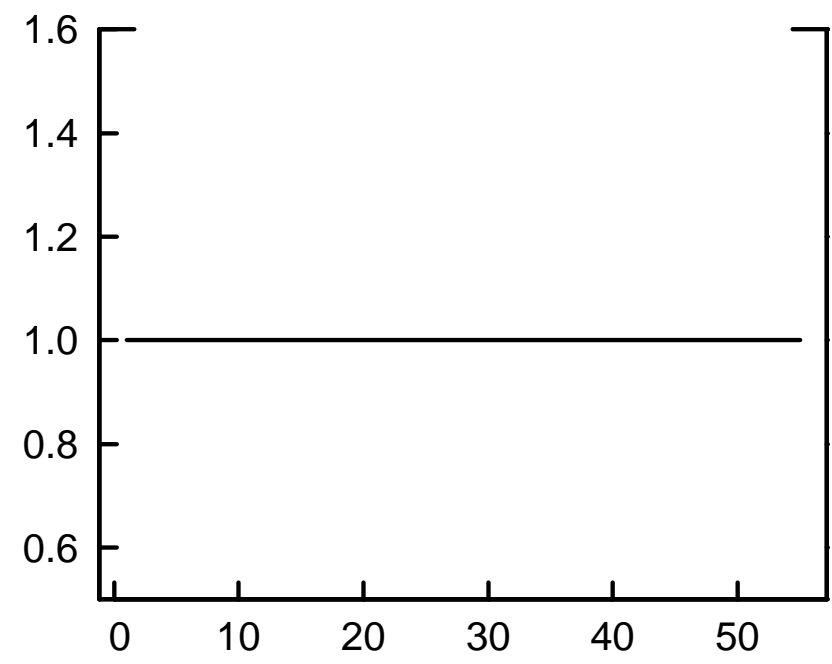

Capital

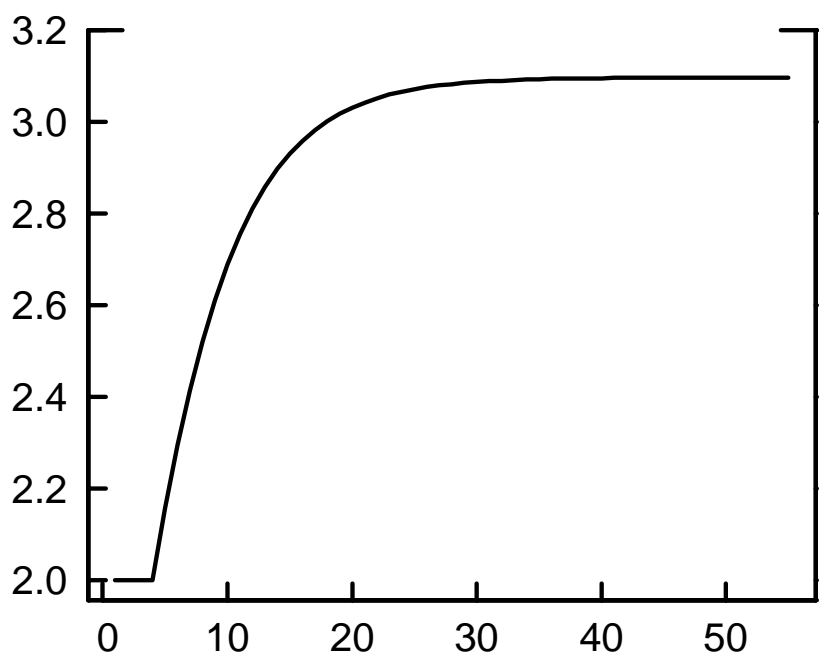

\section{Market}

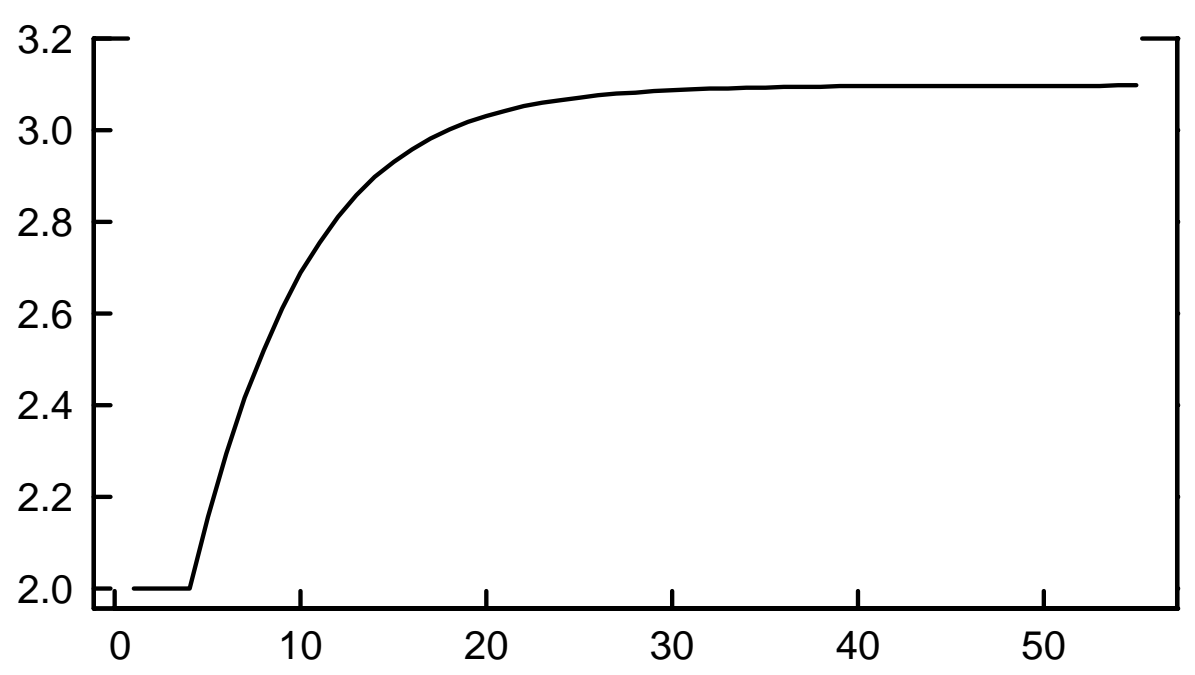


Figure 3A

\section{Dynamics with Moderate Adjustment Costs}

Investment

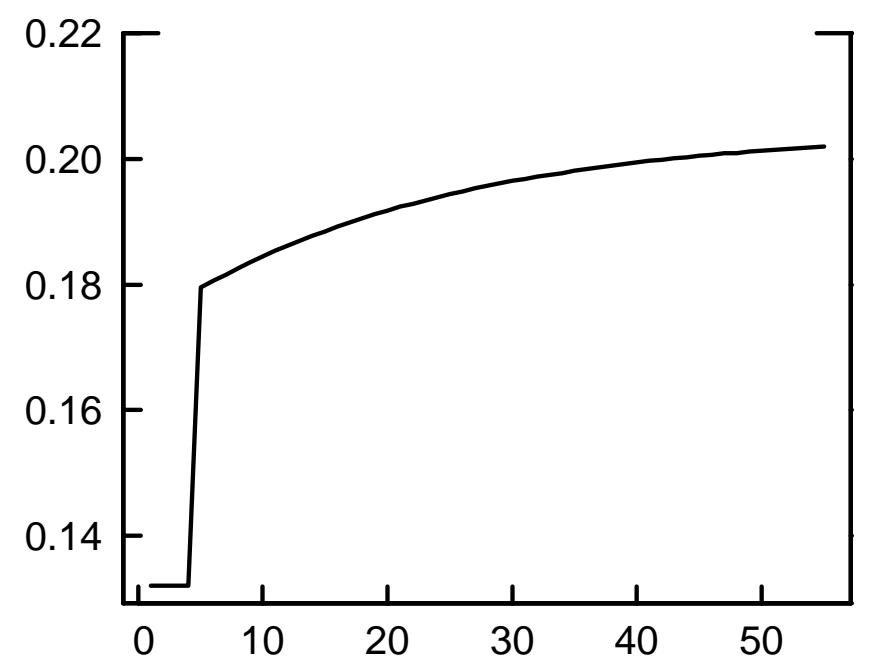

Output

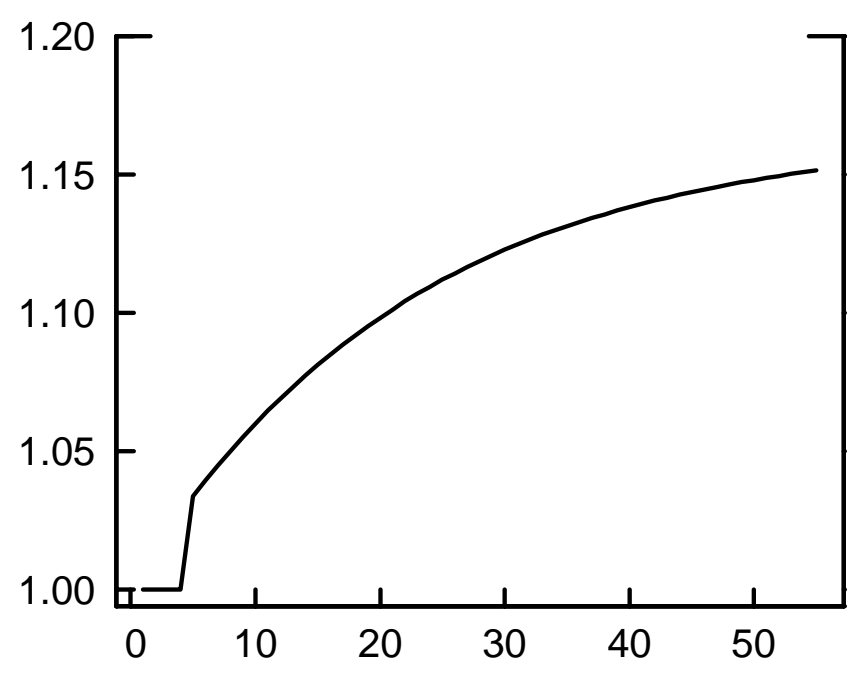

Investment Rate

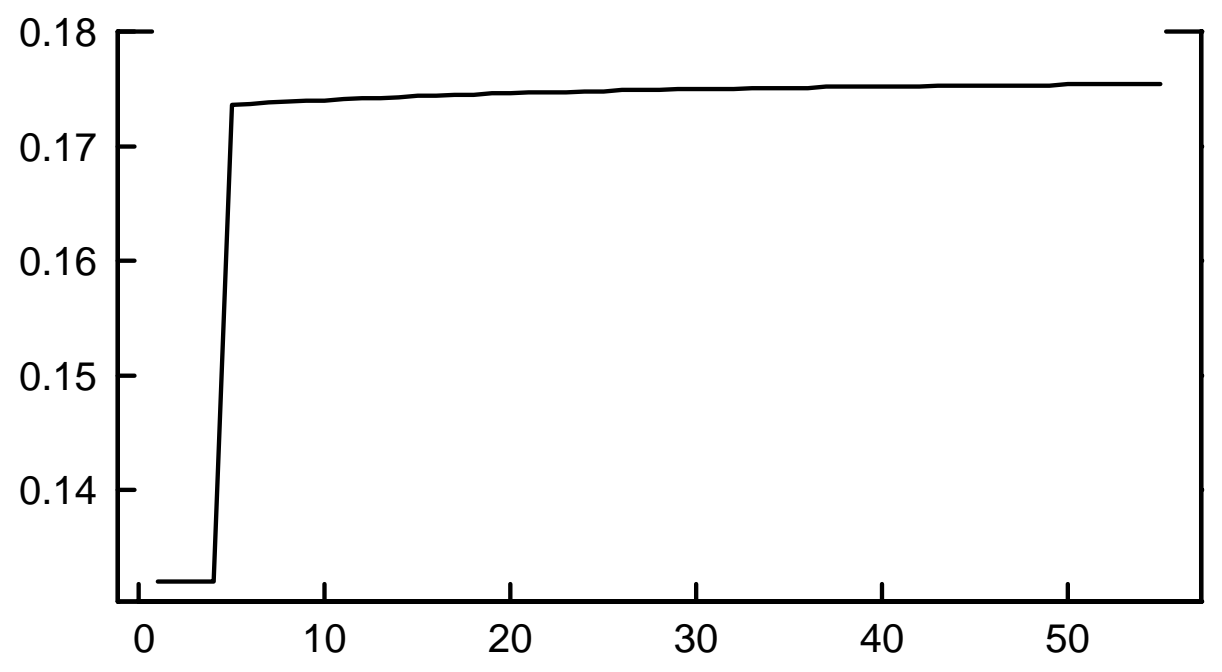


Figure 3B

\section{Dynamics with Moderate Adjustment Costs}

Price of Capital

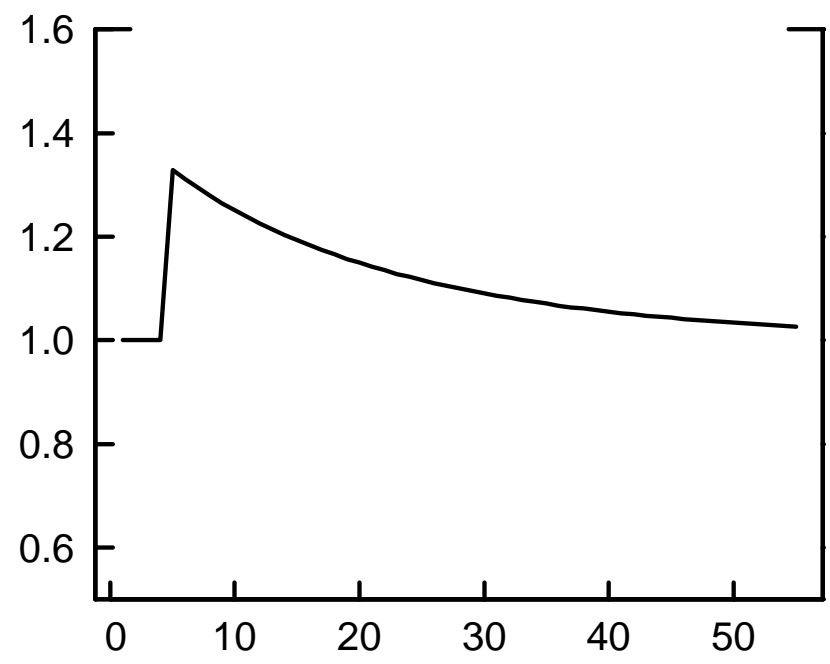

Capital

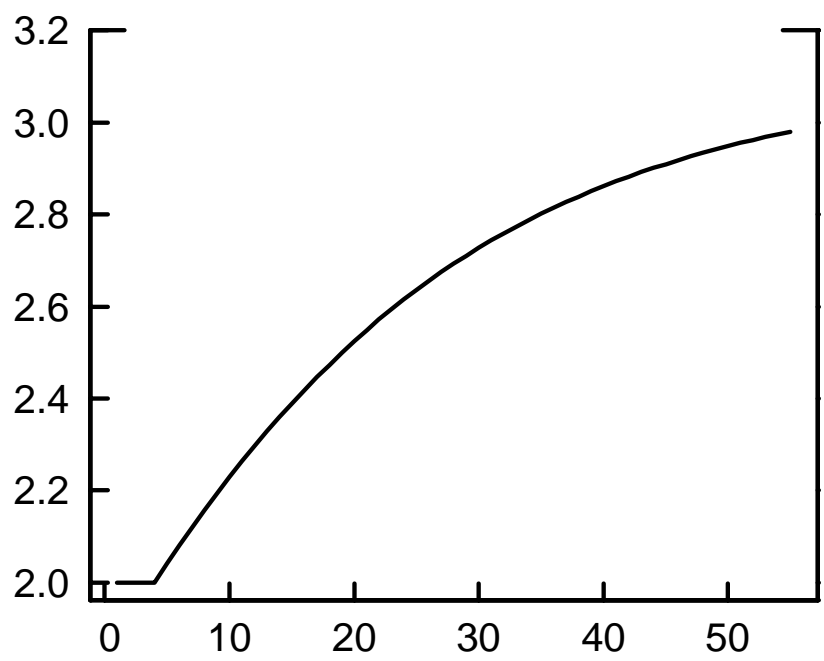

\section{Market}

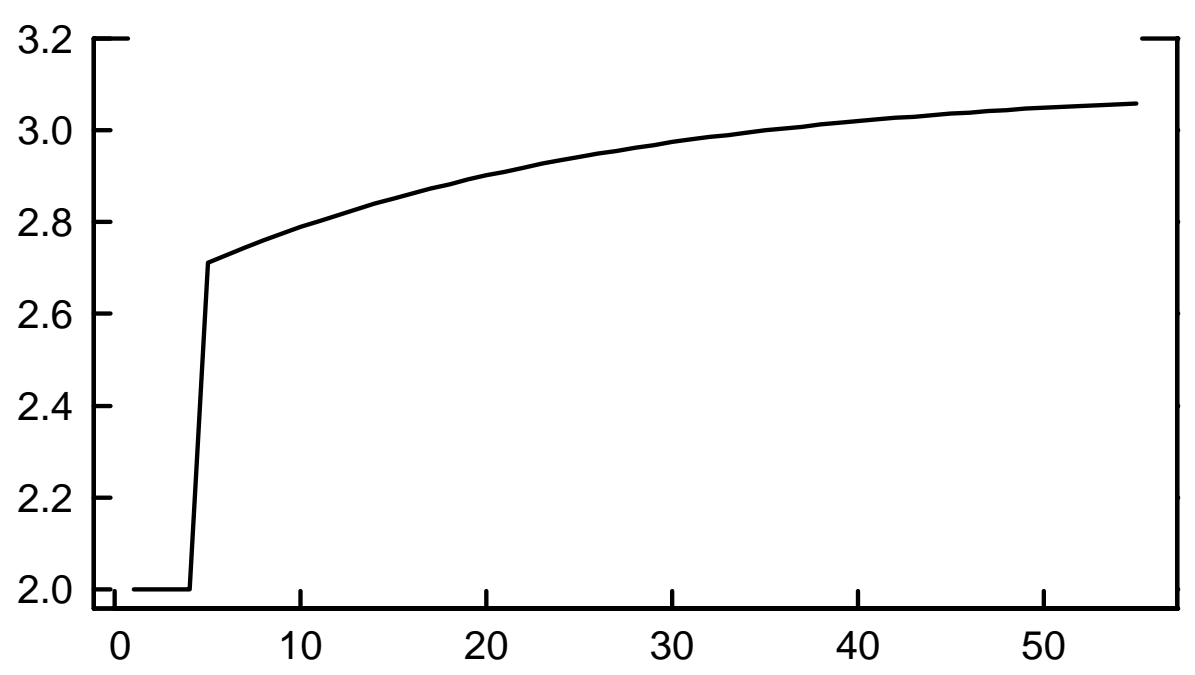


Figure 4A

Dynamics with High Adjustment Costs

Investment

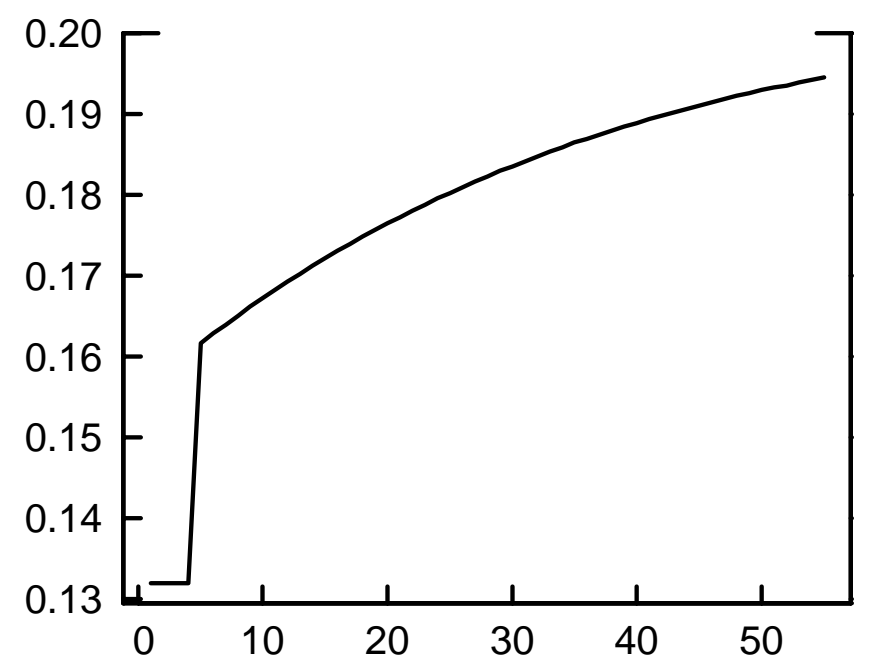

Output

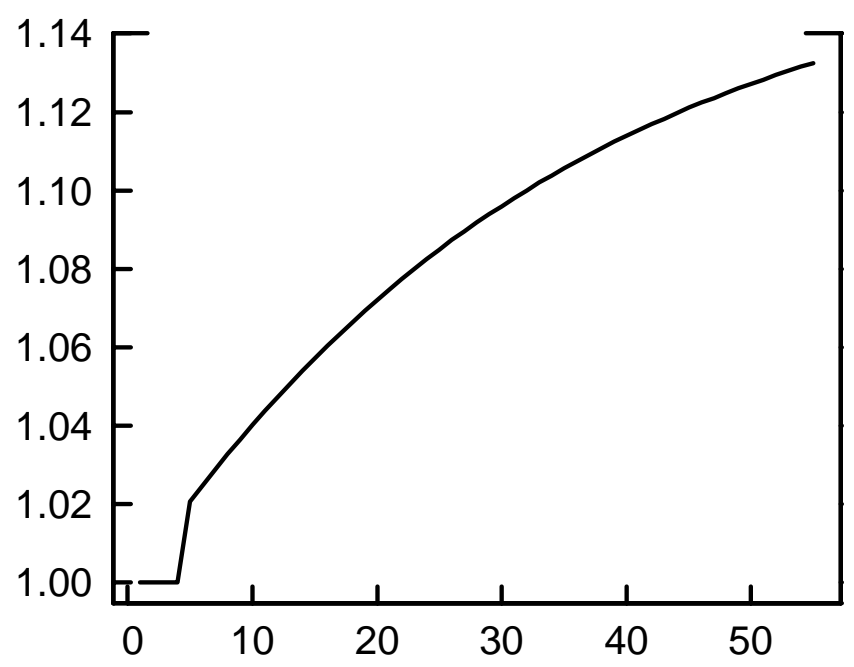

Investment Rate

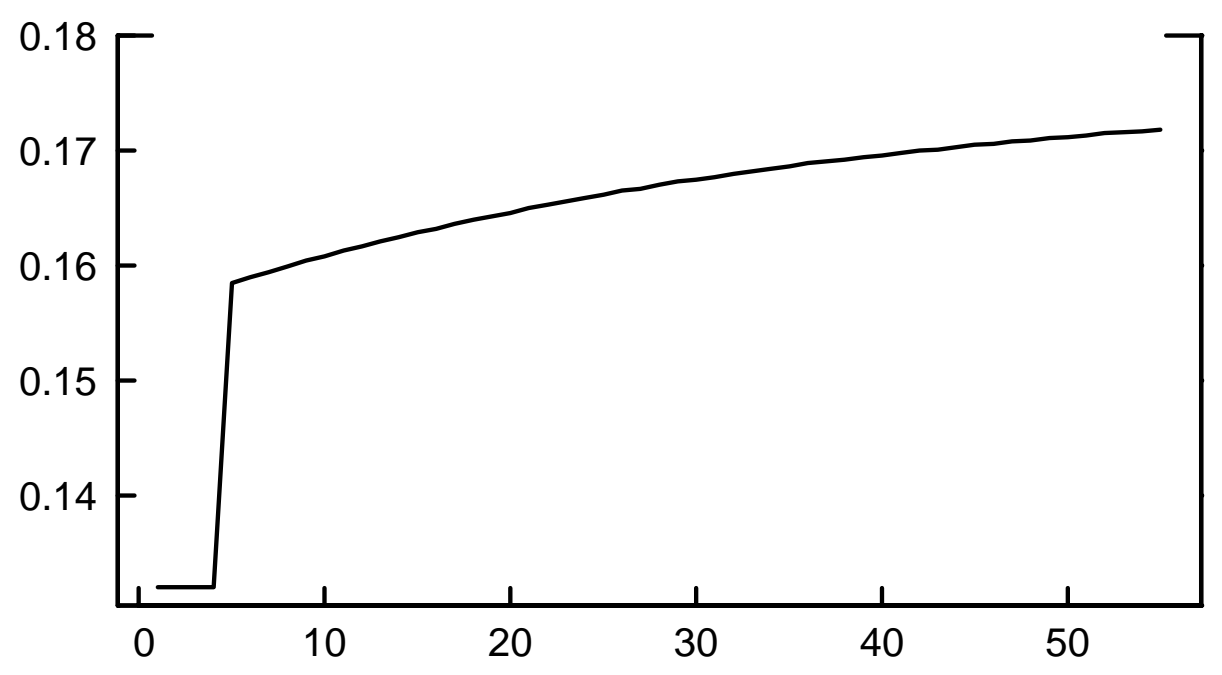


Figure 4B

Dynamics with High Adjustment Costs

Price of Capital

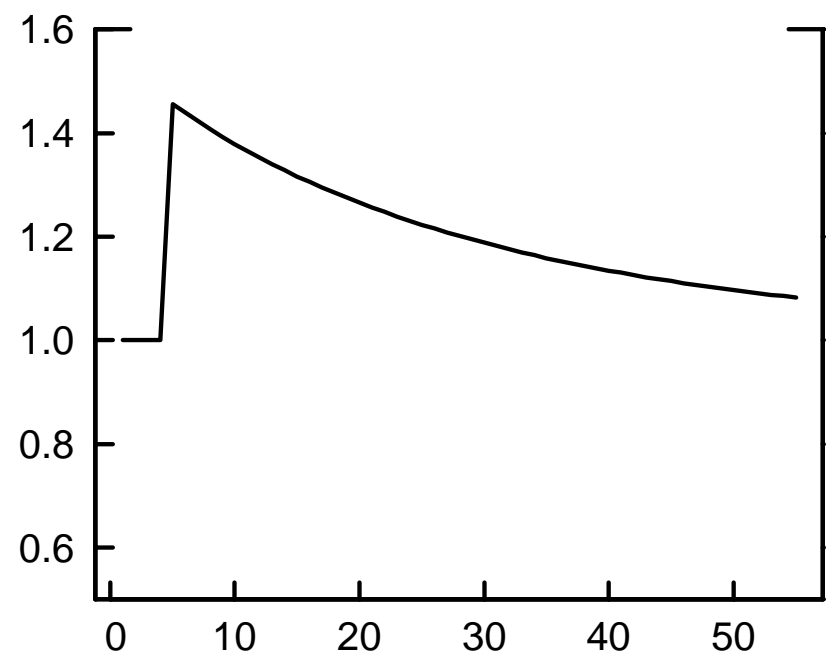

Capital

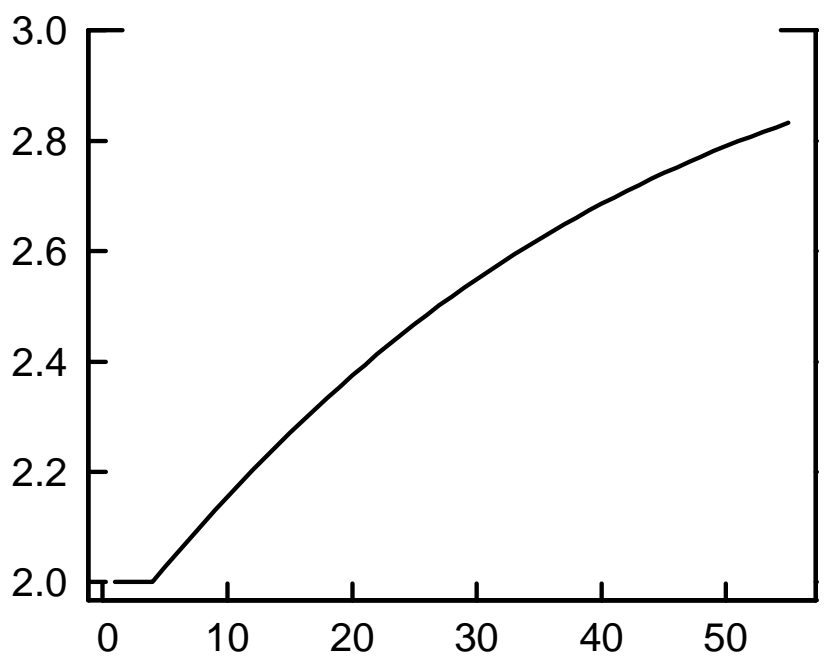

\section{Market}

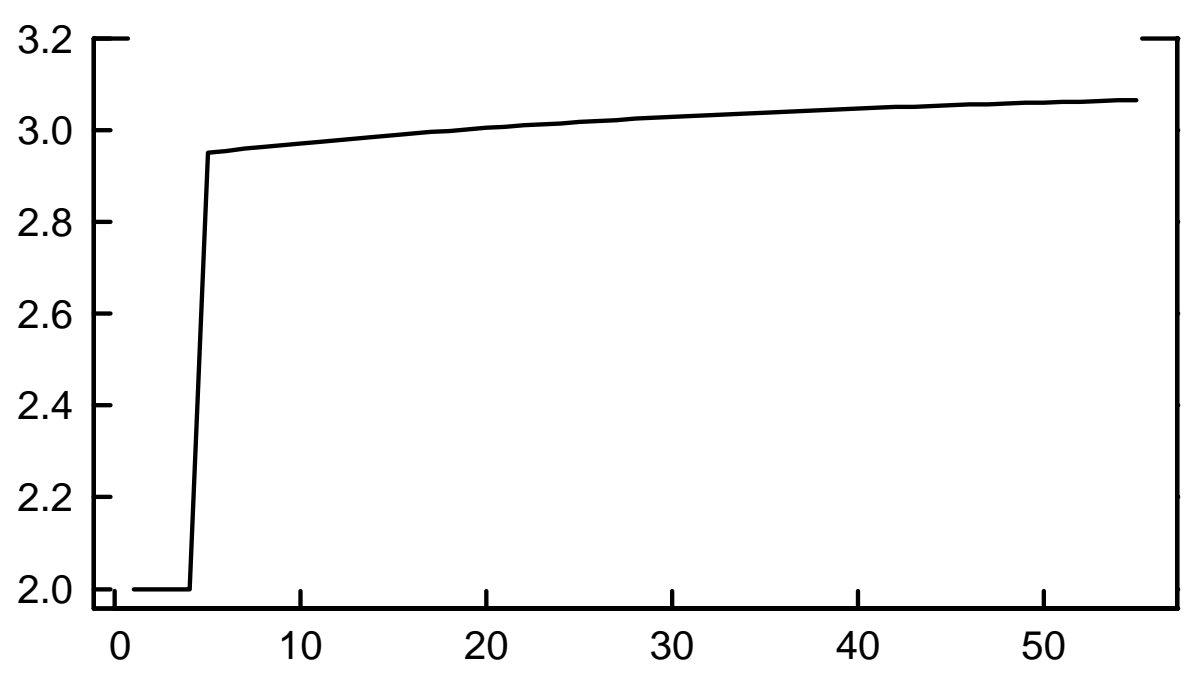




\section{Figure 5 \\ The Investment Share of Output (I/Y)}
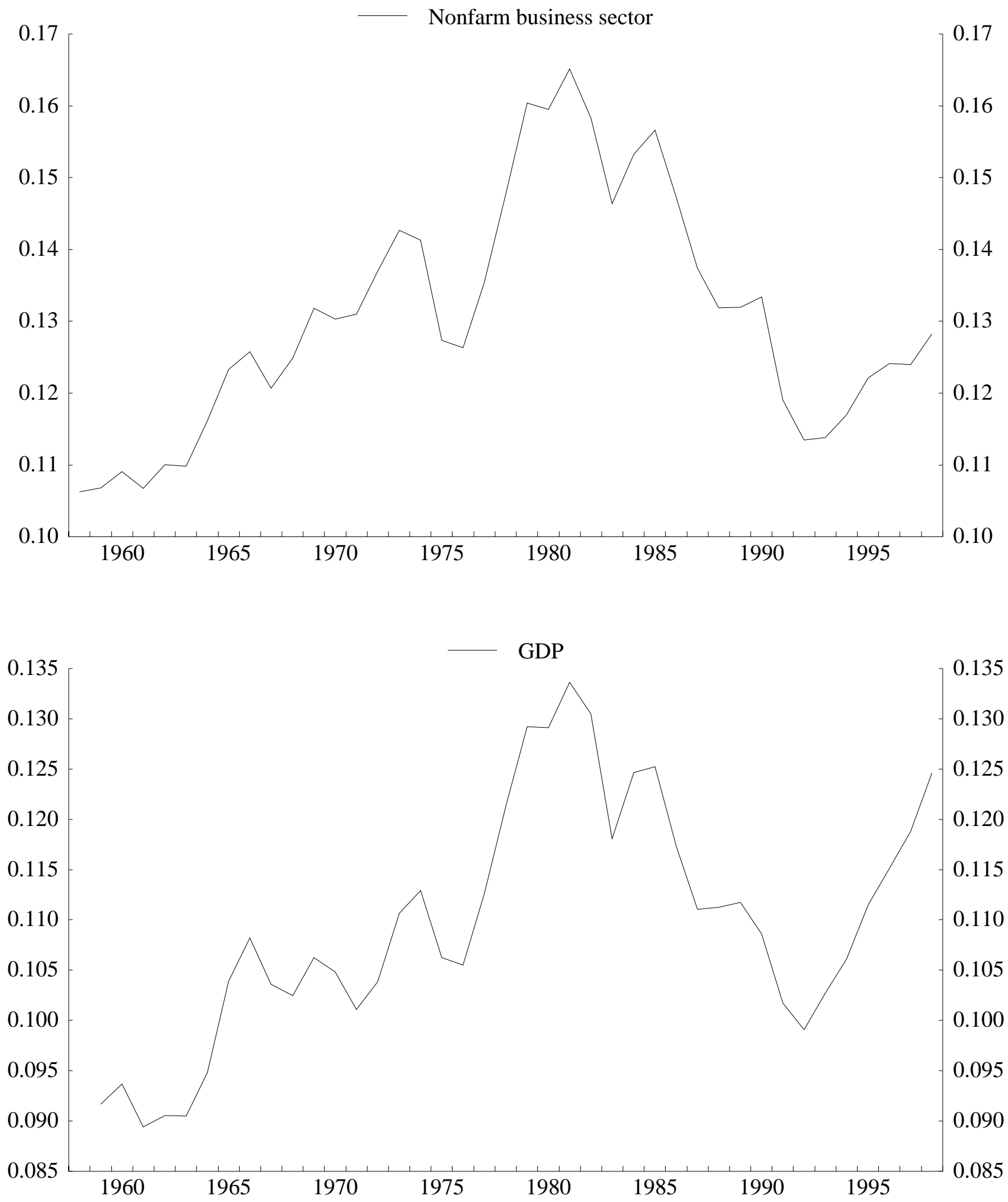